\title{
Direct Extraction of DNA from Soils for Studies in Microbial Ecology
}

\author{
Mark A. Schneegurt ${ }^{\star 1,2}$, Sophia Y. Dore ${ }^{2,3}$, and Charles \\ F. Kulpa, Jr. ${ }^{2,3}$ \\ ${ }^{1}$ Department of Biological Sciences, Wichita State \\ University, Wichita, KS 67260, USA \\ ${ }^{2}$ Center for Environmental Science and Technology, \\ University of Notre Dame, Notre Dame, IN 46556, USA \\ ${ }^{3}$ Department of Biological Sciences, University of Notre \\ Dame, Notre Dame, IN 46556, USA
}

\begin{abstract}
Molecular analyses for the study of soil microbial communities often depend on the extraction of DNA directly from soils. These extractions are by no means trivial, being complicated by humic substances that are inhibitory to PCR and restriction enzymes or being too highly colored for blot hybridization protocols. Many different published protocols exist, but none have been found to be suitable enough to be generally accepted as a standard. Most direct extraction protocols start with relatively harsh cell breakage steps such as bead-beating and freeze-thaw cycles, followed by the addition of detergents and high salt buffers and/ or enzymic digestion with lysozyme and proteases. After typical organic extraction and alcohol precipitation, further purification is usually needed to remove inhibitory substances from the extract. The purification steps include size-exclusion chromatography, ion-exchange chromatography, silica gel spin columns, and cesium chloride gradients, among others. A direct DNA extraction protocol is described that has been shown to be effective in a wide variety of soil types. This protocol is experimentally compared to several published protocols.
\end{abstract}

\section{Introduction}

Environmental microbiologists are growing more dependent on enumeration and detection methods that use molecular biology techniques rather than traditional culture techniques. Enrichment media used to culture microbes in the laboratory are inherently selective and only a subpopulation of the microbes in an environmental sample will grow on any given medium. Even if several different media and growth conditions are used, many of the native microbes will not grow in the laboratory. Using traditional culture techniques to measure the biodiversity of an environmental sample will underestimate species richness and skew measurements of species evenness. The most often cited research addressing this issue suggests that

*For correspondence. Email mark.schneegurt@wichita.edu; Tel. 316-978-6883; Fax. 316-978-3772. less than $1 \%$ of microbes in the environment can be cultured in the laboratory using current methods (Torsvik et al., 1990). Although this value can be debated, it is generally accepted that culture-based methods miss much of the microbial diversity in environmental samples.

Microbial ecologists have turned to cultureindependent methods for community analysis. Rather than isolating microbes, molecular biology techniques are used to isolate and compare the sequences of specific genes (Atlas et al., 1992; Madsen, 1998; Schneegurt and Kulpa, 1998). Taxonomic designations can be derived from phylogenetic analyses of rDNA gene sequences. Whole community DNA extracts are subjected to PCR amplification directed broadly at rDNA sequences or at the rDNA genes of specific clades of organisms. The resulting mixture of rDNA amplicons can be cloned into an appropriate vector and individual amplified rDNA genes methodically sequenced or segregated by RFLP analysis prior to sequencing. DGGE or SSCP analyses also can be used to separate rDNA amplicons that have similar lengths, but different melting points or secondary structures, and hence different primary sequences. Other types of fingerprinting analyses can be used as well. In any case, the success of the project depends on obtaining DNA extracts that are in sufficient quantity and of sufficient purity to be manipulated using these sensitive molecular biology protocols.

Soils present some of the most difficult challenges to the development of suitable extraction and purification procedures. The complex matrix of soil harbors a variety of substances that inhibit the activity of polymerases and restriction enzymes or interfere with hybridization and detection protocols (Steffan et al., 1988; Demeke and Adams, 1992; Tsai and Olson, 1992). Of particular concern are humic and fulvic acids found in great abundance in soils of high organic content that are subject to natural degradation. These fractions are such complex mixtures of related compounds that they demonstrate a broad spectrum of solubilities and charge characteristics. It is difficult, if not impossible, to find extraction and separation conditions that can remove all humic substances from soil DNA extracts. Notice that this review will present a wide range of methods for purifying DNA extracts, but none of these has been shown to be robust and general enough to be accepted by the scientific community as a standard protocol.

Extraction of DNA from soils requires no culturing or growth of the organisms. The procedures can be divided into two groups. In one case, soil samples are exposed to some mild physical and/or chemical disruptions meant to dislodge microbes adhered to soil surfaces (Torsvik, 1980; Holben et al., 1988; Steffan et al., 1988; Josephson et al., 1991; Jacobsen and Rasmussen, 1992; Holben 1994; Courtois et al., 2001). The free microbes are then separated from the soil matrix before DNA extraction begins. The 
second and more popular method is the direct extraction of DNA from soil. Harsh physical and/or chemical disruptions are used to break open cells while still in the soil matrix. The DNA is then extracted and purified from this messy mixture. Each of these methods have both positive and negative aspects in terms of their efficiency and ability to generate DNA extracts that truly represent the natural microbial community.

\section{Sample Handling Issues}

The way that samples are taken, transported, and stored prior to extraction is important for those interested in studying the microbial ecology of native communities. By its very nature, sampling soils physically disrupts soil structure in a way that can alter the microbial community. Therefore, it is important to extract or freeze the samples as quickly as possible. The best method is to freeze samples on dry ice taken to the field site and then to store the samples in an ultralow freezer in the laboratory. Unfortunately, there are many published works where soil samples were stored on the benchtop for long periods or stored at $4{ }^{\circ} \mathrm{C}$ for hours or days before extraction. This kind of storage fundamentally changes the microbial community and results obtained using molecular phylogeny methods will not accurately describe the original native community. For example, Pseudomonads tend to proliferate and come to dominate samples left in a refrigerator, even over short periods of hours or days. The resulting community does not resemble the original community.

It is clear that microbial communities in soils vary greatly over small spatial and temporal scales. Composite sampling where several (five or more) small samples are collected in a limited area $\left(1 \mathrm{~m}^{2}\right)$ is a good method for damping the variations. Adequate mixing is necessary and extraction should be performed on gram quantities of soil to reduce nugget effects. Often soils need to be sieved (2 $\mathrm{mm}$ ) before extraction to remove large debris and rocks. This can be done when frozen samples are thawed prior to extraction. It is important that as little manipulation as possible is done in the field before freezing the samples to limit changes in the community due to physical disruption.

One of the more challenging aspects of sampling soils in the field is cleanliness. It is difficult, if not impossible, to take samples using aseptic techniques in the field. Sampling materials like corers, spades, and spatulas can be sterilized by autoclaving and/or rigorous UV irradiation to limit contamination of the samples. However, windblown materials can be a considerable problem in the field. One must also be sensitive to the distinctions between autochthonous and allochthonous microbes. For example, if a site is subject to flooding, defining which organisms are native to the flood plain and which were recently deposited from the stream becomes difficult.

\section{Cell Breakage}

Direct DNA extraction methods all include steps to break microbial cells within the soil matrix. Microbes are not separated from soil or grown in culture before breaking the cells to release their DNA. Many protocols include several breakage steps that each use a different physical or chemical mechanism. There are significant issues associated with breakage methods that influence the quality of the data obtained from the DNA extracts. It is generally accepted that the great advantage of culture-independent methods of examining microbial communities is that these are unbiased by the ability or inability of particular species to grow in culture and hence give a more accurate picture of the native community. However, particular breakage regimes could bias the content of the DNA extract toward specific groups of bacteria. Gram-negative cells tend to break more easily than Gram-positive cells. Thus, more mild breakage regimes may not sufficiently break Grampositive cells or their spores and can potentially enrich the extracts with DNA from Gram-negative organisms. However, since Gram-negative cells break open more easily, harsher breakage regimes may significantly shear the released DNA. Thus, harsher methods may enrich for DNA from Gram-positive organisms. In many cases, fairly small DNA fragments are targeted for amplification, so that shearing is not as important. Most laboratories use relatively harsh breakage regimes.

The most commonly used protocols are based on that of Tsai and Olsen (1991). Here freeze-thaw cycles are used to break the cells in soil before DNA extraction (Picard et al., 1992; Erb and Wagner-Döbler, 1993; Herrick et al., 1993; Moré et al., 1994; Cullen and Hirsch, 1998; Edgcomb et al., 1999). Soil slurries are alternately rapidly frozen in a dry ice-acetone, dry ice-ethanol, or liquid nitrogen bath and then rapidly thawed in a 60 to $100^{\circ} \mathrm{C}$ water bath. Beadbeating is another popular cell breakage method (Ogram et al., 1987; Smalla et al., 1993; Tebbe and Vahjen, 1993; Holben, 1994; Moré et al., 1994; Cullen and Hirsch, 1998; Courtois et al., 2001). Soil slurries are supplemented with small zirconia/glass beads and then violently shaken at more than $500 \mathrm{rpm}$ to physically disrupt cells. Modified vortex mixers or specially design shakers can be used. These are generally smaller and less sophisticated versions of the long-lived carbon dioxide-cooled Braun homogenizers. The size of the beads used, the period of milling, and the breakage buffer composition vary between protocols. In general, an equal volume of beads ( 0.1 to 0.2 $\mathrm{mm}$ ) and soil are added to a breakage medium that may contain detergents and high salt concentrations and the mixture is milled for 3 to 15 minutes, often in the cold. Direct grinding of soils in liquid nitrogen using a mortar and pestle (Volossiouk et al., 1995; Ranjard et al., 1998; Edgcomb et al., 1999) and ultrasonication (Picard et al., 1992) also have been reported.

Chemical breakage methods are used in combination with physical methods in many protocols. The most popular detergent treatment includes SDS at $1 \%$ and salt concentrations of $1 \mathrm{M}$ or more, often coupled with heating and shaking (Steffan et al., 1988; Bruce et al., 1992; Herrick et al., 1993; Smalla et al., 1993; Holben, 1994; Lovell and Piceno, 1994; Moré et al., 1994; Volossiouk et al., 1995; Porteous et al., 1997; Cullen and Hirsch, 1998; Edgcomb et al., 1999). A hot-SDS lysis method was first presented by Selenska and Klingmüller (1991). A persistent problem with soil extractions is that DNA tends to adsorb to soil 
particles giving lower yields (Greaves and Wilson, 1969; Lorenz and Wackernagel, 1987; Ogram et al., 1988). Adding detergents and salts can help to alleviate this problem, although SDS can inhibit PCR if not removed in subsequent steps (Weyant et al., 1990). Some protocols, particularly commercially available kits, tend to use strong chaotropic agents like guanidinium salts (Tsai and Olson, 1990; Porteous et al., 1997). Degradatory enzyme digestion steps are often included in breakage regimes. Incubation with lysozyme (Hilger and Myrold, 1991; Rochelle and Olson, 1991; Tsai and Olson, 1991; Erb and WagnerDöbler, 1993; Herrick et al., 1993) followed by incubation with a protease (Porteous and Armstrong, 1991; Tebbe and Vahjen, 1993; Ranjard et al., 1998; Courtois et al., 2001) often precedes the addition of detergent and salt. Although these steps may help to liberate DNA from cells, a cautionary note must be added suggesting that DNA degradation may occur during the long (an hour or more) and warm $\left(37^{\circ} \mathrm{C}\right)$ enzymic digestions.

Our laboratory has had success with a breakage regime that includes many of these elements. Soil slurries are first subjected to bead beating (with $0.1 \mathrm{~mm}$ beads) in a simple phosphate-buffered solution containing $1 \%$ SDS. Proteinase $\mathrm{K}$ is added to $100 \mu \mathrm{g} \mathrm{ml}^{-1}$ and incubated for $1 \mathrm{~h}$ at $37^{\circ} \mathrm{C}$. This is followed by 4 cycles of freeze-thaw using a dry ice-ethanol bath and an $80^{\circ} \mathrm{C}$ water bath $(3 \mathrm{~min}$ in each per cycle). Direct counting of cells with acridine orange staining and direct plating experiments demonstrated that in excess of $90 \%$ of the observable cells and viable cells were broken using this protocol.

\section{Nucleic Acid Extraction}

The extraction and collection of nucleic acids from the soil homogenates generally follow standard protocols that include organic extraction and alcohol precipitation (Sambrook et al., 1989). The soil homogenates can be centrifuged to remove soil debris, but often the extractions proceed directly with the homogenate. Many protocols facilitate breakage and the subsequent deproteination step by adding CTAB and increasing the salt concentration (Zhou et al., 1996; Porteous et al., 1997; Ranjard et al. 1998; Edgcomb et al., 1999). This may also help remove humic materials. Our protocol brings the sodium chloride concentration to $4.5 \%$ and the CTAB concentration to $1.2 \%$ followed by a 20 -min incubation at $65^{\circ} \mathrm{C}$. Organic extraction with a variety of phenol and chloroform combinations is included in the extraction protocols to deproteinate the homogenate and remove a good deal of the humic and pigmented components. In some cases, phenol extraction(s) is followed by chloroform extraction, while others extract with a mixture of phenol and chloroform. We extract homogenate supernatants with Tris-buffered phenol $(\mathrm{pH}$ 8.0) and then with water-saturated chloroform:isoamyl alcohol solution (24:1).

Nucleic acids are precipitated from the aqueous phase of the organic extractions by the addition of alcohol. The soil extraction protocols use either isopropanol (one volume) or ethanol (two volumes). In most cases, the mixture is cooled, often overnight, before centrifugation to collect nucleic acids. The pellets, which are usually large and darkly colored from the humic constituents, are dried in vacuo and resuspended in a small amount of buffer. Resuspension can be slow and usually requires heating $\left(65^{\circ} \mathrm{C}\right.$ for $1 \mathrm{~h}$ ) or prolonged incubation (overnight at $4^{\circ} \mathrm{C}$ ). These crude DNA preparations can often be used for molecular analyses, but in most cases are too contaminated with enzyme inhibitors for amplification by PCR or too highly colored for blot hybridizations. Extractions from sediments and other soils with low organic contents are less troublesome. In some cases, extensive dilution of the extract will allow for direct PCR amplification from these crude DNA extracts.

\section{DNA Purification}

It is at this point that the published protocols tend to greatly diverge. Crude DNA extracts from soils are usually too impure to allow for molecular analyses and need to be further purified. There is no agreement as to the most effective method of purification. Many of the protocols appear to be idiosyncratic and only effective on the soil type for which they were developed. Other protocols claim to be more generally applicable, but results in individual laboratories vary considerably. We have tried several common protocols with a variety of soils and will report about our experiences here.

The use of some type of silica gel or silica membrane separation is perhaps the most popular purification step (Porteous and Armstrong, 1991; Smalla et al., 1993; Moré et al., 1994; Zhou et al., 1996; Ranjard et al., 1998). Many commercially available clean-up kits such as Promega's Wizard DNA clean-up kit and the Bio101 (Vista, CA) FastDNA Spin kit (analogous to Gene-Clean) use silica gel spin columns to remove humic materials from DNA extracts. Silica gel (glass milk) can be purchased separately and used without purchasing entire kits. The silica gel binds to humic materials and DNA initially, and some humic acids can be sequentially eluted from the matrix. This same technology is found in the Elutip d syringe-tip filters used by Picard et al. (1992). Our protocol includes two silica gel mini-columns as the final polishing steps. After organic extractions and alcohol precipitation, our DNA is purified by passage through a DEAE-cellulose column, reprecipitated, and then passed through a Wizard DNA clean-up column and a Bio101 FastDNA spin column. As discussed below, we did not find the silica gel protocols alone to be effective in removing sufficient amounts of humic materials from DNA extracts of several soil types.

Although not as commonly used, we found ionexchange chromatography to be an excellent way to remove humic materials from soil DNA extracts. DEAEcellulose columns are commonly used for purifying tRNAs and have been used for DNA extracts (Holley et al., 1961; Lovell and Piceno, 1994). Hydroxyapatite column chromatography has been used effectively as well (Markov and Ivanov, 1974; Ogram et al., 1987; Steffan et al., 1988). These column steps are relatively laborious, but the great amount of humic materials removed makes them worthwhile. Syringe-tip ion-exchange columns are available commercially and have been applied to DNA purification from soils (Tebbe and Vahjen, 1993). In our laboratory, 


\begin{tabular}{|c|c|c|c|c|c|c|c|c|}
\hline \multirow[t]{2}{*}{ Soil } & \multirow[t]{2}{*}{ Type } & \multirow[t]{2}{*}{$\%$ Moisture } & \multirow[t]{2}{*}{$\%$ Organic Matter } & \multicolumn{5}{|c|}{ Metal Content ( $\mu \mathrm{g}$ per g dry wt. soil) } \\
\hline & & & & $\mathrm{Ca}$ & $\mathrm{Fe}$ & $\mathrm{Mg}$ & $\mathrm{K}$ & $\mathrm{Na}$ \\
\hline Bendix Woods & Silty clay loam & 28.8 & 10.4 & 7,446 & 17,595 & 2,639 & 17,504 & 2,576 \\
\hline St. Mary's Lake & Loamy sand & 25.1 & 13.6 & 70,667 & 62,038 & 10,440 & 10,958 & 2,088 \\
\hline Yellowstone Forest & Clay loam & 43.3 & 46.8 & 6,341 & 11,240 & 2,269 & 15,800 & 5,959 \\
\hline Rainforest & Silt loam & 43.5 & 22.0 & 7,456 & 87,899 & 5,774 & 7,495 & 5,863 \\
\hline Spinn Prairie & Silty clay & 13.5 & 6.0 & 6,117 & 10,978 & 2,362 & 14,589 & 4,340 \\
\hline Cornfield & Sandy loam & 8.4 & 4.8 & 8,224 & 26,517 & 5,101 & 18,688 & 4,420 \\
\hline Desert Sand & Loamy sand & 3.4 & 2.9 & 23,622 & 49,219 & 24,567 & 34,015 & 14,860 \\
\hline Marine Sediment & Sand & 20.6 & 0.9 & 7,656 & 17,174 & 4,072 & 10,519 & 3,642 \\
\hline Peat & Peat & 90.2 & 75.0 & 1,388 & 447 & 159 & 846 & 1,905 \\
\hline Yellowstone Clay & Clay & 29.1 & 7.0 & 2,068 & 14,860 & 1,710 & 15,980 & 1,807 \\
\hline
\end{tabular}

crude DNA extracts are applied in a low-salt buffer $(0.1 \mathrm{M}$ $\mathrm{NaCl})$ to small $(2 \mathrm{ml})$ DEAE-cellulose beds held in disposable fritted columns. The DNA is preferentially eluted when the salt concentration of the eluant is raised to 0.5 M. Some humic materials are eluted with the DNA, but the vast majority remains bound to the matrix. In most cases, the DNA extracts obtained after DEAE-cellulose chromatography are not sufficiently pure for PCR or restriction enzyme digestion. The eluted DNA is precipitated with alcohol to reduce its volume and remove salts in preparation for the final silica gel spin column procedures.

Another popular purification method is the use of agarose gel electrophoresis to separate DNA from humic materials (Hilger and Myrold, 1991; Rochelle and Olson, 1991; Herrick et al., 1993; Zhou et al., 1996). Polyacrylamide and dextran gel filtration columns also use size as a basis for separation (Tsai and Olson, 1992; Erb and Wagner-Döbler, 1993; Jackson et al., 1997; Cullen and Hirsch, 1998; Ranjard et al., 1998; Edgcomb et al., 1999). Jackson et al. (1997) compared the effectiveness of Sepharose 4B, Sephadex G-200, and Sephadex G-50 with a diverse set of soils and found Sepharose 4B to be superior. Membrane-based microconcentrators can be used for size separations (Porteous et al., 1997). Molecular sizing will remove much of the humic materials, but since this is such a diverse mixture of materials, a significant amount of humic materials comigrate with the DNA band. Additional purification is often needed. In some cases, a strip of gel containing polyvinylpolypyrrolidone (PVPP) is incorporated a short distance from the wells of an agarose gel. The DNA is unimpeded upon passage through the PVPP strip, while humic materials can be trapped. In other cases, the PVPP is included throughout the gel (Herrick et al., 1993). Some researchers have used PVPP powder in batch or in spin columns to bind humic materials and purify DNA extracts (Steffan et al., 1988; Hilger and Myrold, 1991; Porteous and Armstrong, 1991; Picard et al., 1992; Zhou et al., 1996; Cullen and Hirsch, 1998). Powdered milk also has been used to adsorb humic materials during extractions (Volossiouk et al., 1995).

A very traditional method, cesium chloride gradients, appears to be very effective (Ogram et al., 1987; Steffan

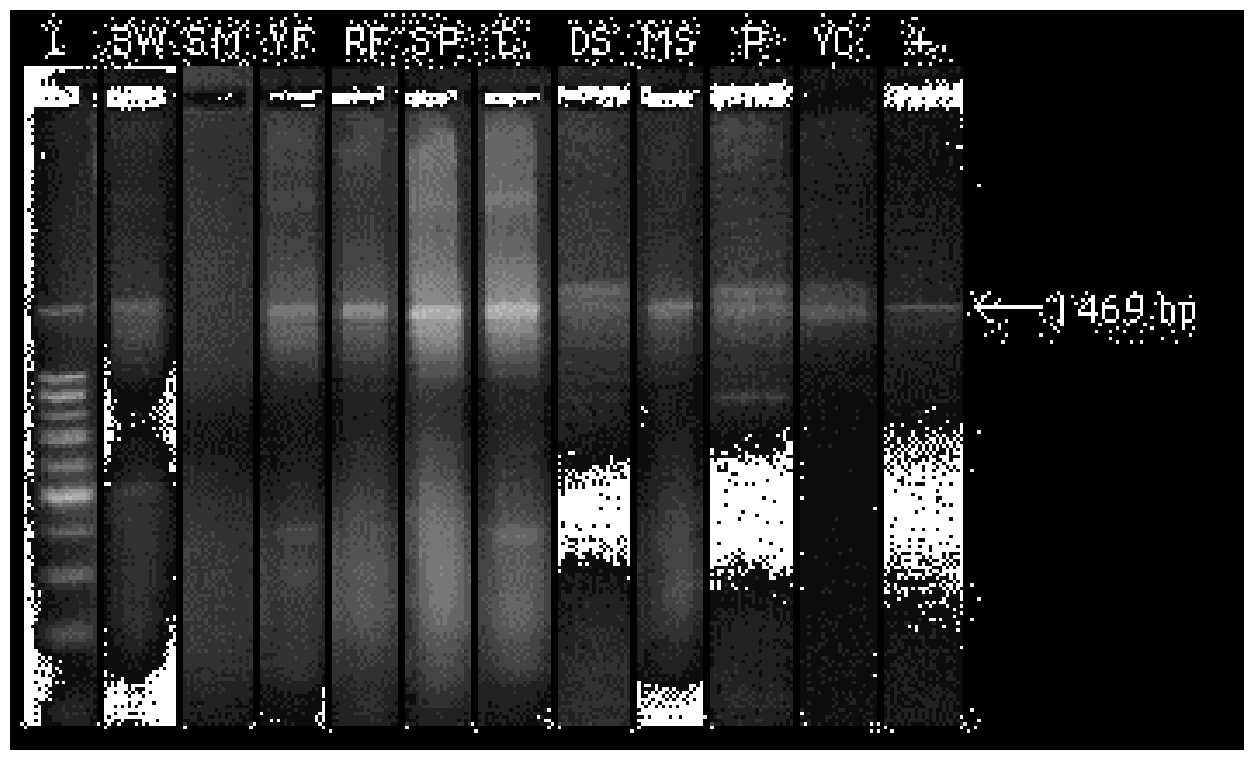

Figure 1. Gel electrophoretic separation of DNA fragments obtained by PCR amplification of 16S rDNA genes in soil extracts produced by the current protocol. $\mathrm{L}=100$-bp DNA ladder, RF = rainforest soil, YF = Yellowstone Forest, $\mathrm{P}=$ peat, $\mathrm{YC}=$ Yellowstone clay, $\mathrm{C}=$ cornfield soil, BW $=$ Bendix Woods soil, MS = marine sediment, DS = desert soil, SP = Spinn Prairie soil, SM = St. Mary's Lake soil, + = pure P. putida culture. 


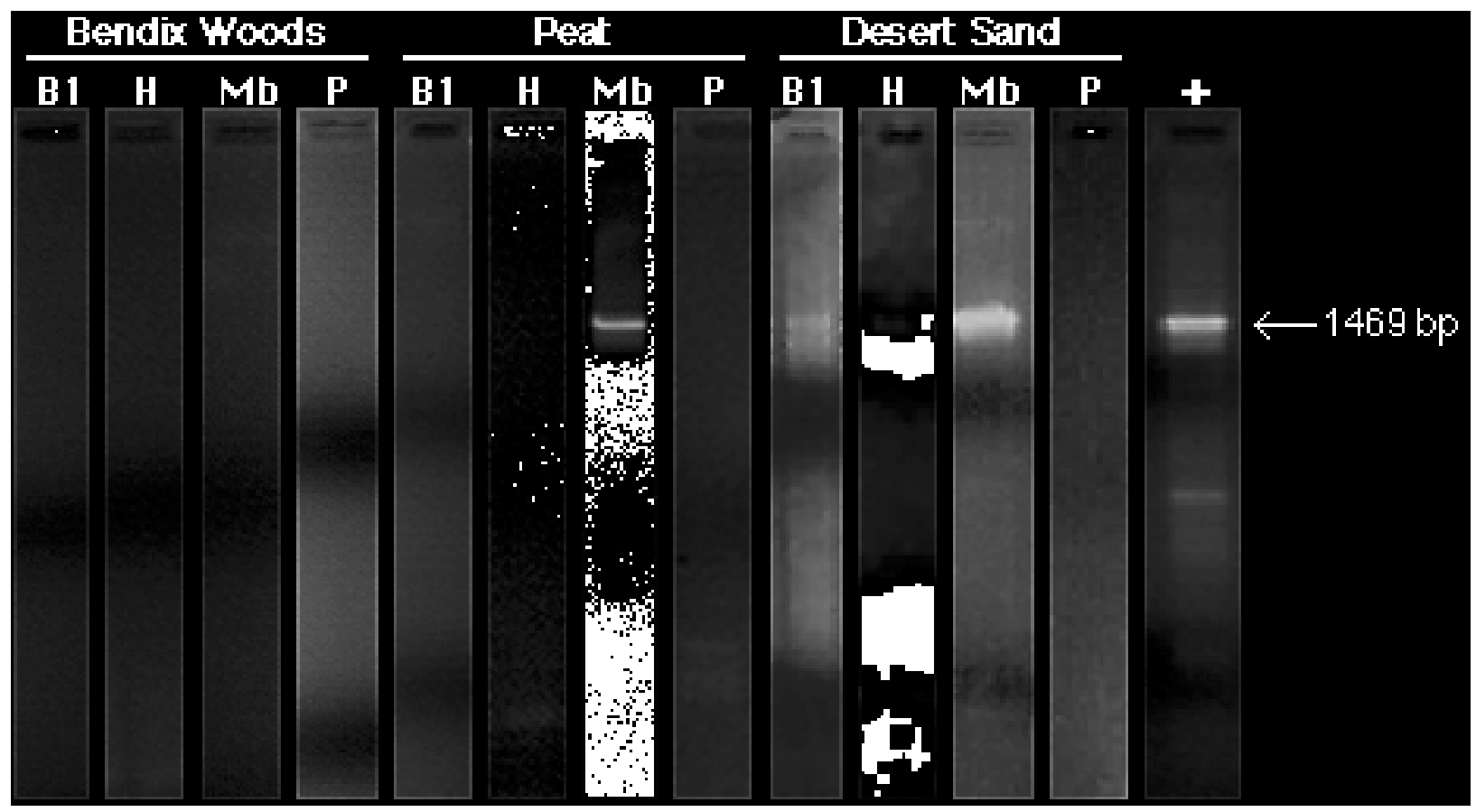

Figure 2. Gel electrophoretic separation of DNA fragments obtained by PCR amplification of 16S rDNA genes in soil extracts produced by published and commercial protocols. B1 = Bio101 FastDNA spin kit for Soil, H = protocol from Herrick et al. (1993), Mb = MoBio Inc. Ultraclean Soil DNA kit, P = protocol from Picard et al. (1992).

et al., 1988; Holben et al., 1988; Porteous et al., 1991; Selenska and Klingmüller, 1991; Bruce et al., 1992; Jacobsen and Rasmussen, 1992; Smalla et al., 1993; Holben, 1994; Lovell and Piceno, 1994; Courtois et al., 2001). These are rather labor intensive protocols that work best with relatively large quantities of DNA. There have been suggestions that differential ethanol precipitations can be used to remove humic materials. Precipitations with 0.1 to 0.5 volumes of ethanol remove some humics. We have not found this protocol to be very effective in the variety of soil types we tested.

\section{Comparison of Protocols}

The DNA extraction protocol used in our laboratory gave extracts pure enough for PCR amplification from a wide range of soils. A PCR primer set directed against Eubacterial 16S rDNA sequences that generates a 1469bp amplicon (pA, pH from Edwards et al., 1989) was used to test the effective purity of the DNA extracts. PCR was performed in $100-\mu \mathrm{l}$ reactions using $1 \mu \mathrm{l}$ of the DNA extracts, and the products were tested by hybridization with an internal probe. The ten soils tested widely differed in type, organic matter content, and metal concentrations, being derived from a disparate set of environments (Table 1). The organic content of the soils ranged from $75 \%$ organic matter in peat to $0.9 \%$ organic matter in marine sediment. Although peat had the highest organic content, it was relatively undegraded material, while the forest soils apparently had the greatest levels of humic materials. Nine of the ten soil DNA extracts were of sufficient purity and abundance to PCR amplify bacterial $16 \mathrm{~S}$ rDNA sequences (Figure 1).
Three of the soils were chosen for further study, a forest soil, a desert sand, and peat. Four previously reported DNA extraction protocols were applied to these soil, that of Herrick et al. (1993), Picard et al. (1992), the MoBio Ultraclean Soil DNA Kit, and the Bio101 FastDNA SPIN Kit for soil. The commercial kits essentially rely on silica gel spin columns for purification of the DNA. The Picard protocol includes PVPP in the breakage buffer and uses three successive passages through Elutip d columns (Schleicher and Schuell Dassel, Germany). The Herrick protocol uses PVPP in an agarose gel for electrophoretic purification of the DNA. Three of the extraction protocols tested generated PCR amplicons from the desert sand (Figure 2). The Herrick protocol gave no visible products from desert sand. No visible PCR products were generated from the forest soil. The MoBio procedure yielded a suitable extract from peat. The Picard procedure also gave a faint positive reaction with peat extracts. In our hands, these protocols worked well for soils that did not have high humic contents, but were unable to provide DNA extracts that were suitable for PCR from soils rich in humic materials.

To distinguish between extracts that were poor due to inhibitory substances from those that simply did not have sufficient yields to be effective, an inhibition assay was developed where a known amount of a specific functional gene, the $x y l E$ gene from Pseudomonas putida mt-2, was amplified in the presence of soil DNA extracts. When the Bio101 or MoBio protocols were used to extract DNA, the extracts obtained from Bendix Woods soil and from peat were inhibitory to PCR when $1 \mu \mathrm{L}$ was added to the 100 $\mu \mathrm{L}$ reaction volume, while the extracts from sand were not inhibitory when $5 \mu \mathrm{L}$ were added. The Picard et al. 


\begin{tabular}{lccc}
\hline \multicolumn{3}{c}{ Table 2. Yield and metal content of DNA extracts } \\
\hline \multicolumn{1}{c}{ Soil } & Yield & $\begin{array}{r}\text { Fe Content } \\
\text { ( } \mu \text { g per g dry wt. soil) }\end{array}$ \\
\hline Bendix Woods & 33.8 & 0.0837 & 0.3725 \\
St. Mary's Lake & 35.3 & 0.0326 & 0.2069 \\
Yellowstone Forest & 25.8 & 0.0268 & 0.3100 \\
Rainforest & 28.5 & 0.0372 & 0.3388 \\
Spinn Prairie & 13.8 & 0.0251 & 0.1526 \\
Cornfield & 7.9 & 0.0465 & 0.1946 \\
Desert Sand & nd & 0.0468 & 1.1595 \\
Marine Sediment & 3.7 & 0.0453 & 0.2163 \\
Peat & nd & 0.0526 & 0.3947 \\
Yellowstone Clay & 1.7 & 0.0312 & 0.3209 \\
\hline
\end{tabular}

procedure yielded an extract from Bendix Woods soil that was inhibitory to PCR at the $1-\mu \mathrm{L}$ level, but the peat and sand extracts were not. None of the extracts obtained using the Herrick procedure were inhibitory to PCR. Most of the extracts obtained by the new protocol were not inhibitory to PCR even when $5 \mu \mathrm{L}$ were added. One $\mu \mathrm{L}$ of DNA extract obtained using the current protocol on St. Mary's Lake soil was enough to inhibit PCR and $3 \mu \mathrm{L}$ of the Yellowstone forest soil also was inhibitory. The protocol developed by Herrick et al. did not result in an extract that was inhibitory to PCR, but still no PCR products were obtained with this protocol. A likely explanation for this is that this procedure resulted in a low yield of DNA.

The yield of DNA using the current protocol varied greatly with soil type, ranging from 25 to $35 \mu \mathrm{g}$ DNA per gram dry weight soil for forest soils to $1.7 \mu \mathrm{g}$ DNA per gram dry weight soil for the Yellowstone clay (Table 2). The yield of DNA obtained by the current protocol was generally similar to reported values (Tebbe and Vahjen 1993, Zhou et al. 1996, Frostegård et al. 1999 [non-purified yields], Miller et al. 1999). Two soils gave yields of DNA that were lower than the rest of the soils tested. One was the Marine Sediment which has very low organic content and likely low biomass abundance. The other soil giving a low yield was the Yellowstone Clay. Frostegård et al. (1999) found that DNA adsorbs strongly to soil colloids in clay-rich soil

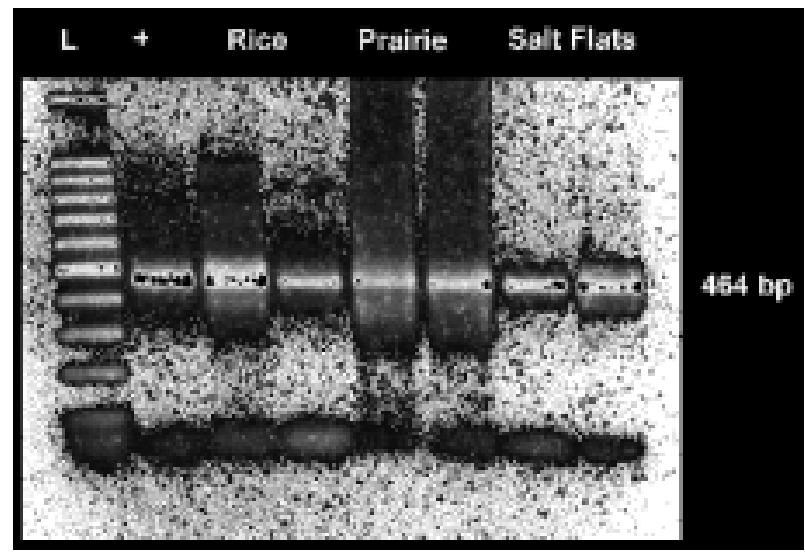

Figure 3. Gel electrophoretic separation of DNA fragments obtained by PCR amplification of nifH genes in DNA extracts produced by the current protocol from two ricefield soils, two prairie soils, and two salt flats hypersaline soils. L = 100-bp DNA ladder, + = pure Anabaena culture. and were unable to recover any DNA from clay-rich soil even after seeding it with up to $50 \mu \mathrm{g}$ of DNA.

The sensitivity of our soil extraction protocol was determined by seeding soil samples prior to extraction with known amounts of bacteria that contain a kanamycinresistance gene unlikely to be abundant in nature. We were able to detect the presence of bacteria when added to Bendix Woods soil at $10^{2}$ cells.gram ${ }^{-1}$. Tsai and Olson (1992) were able to detect $2 \times 10^{5}$ cells $\cdot \mathrm{gram}^{-1}$ from soil rich in humic acids. Degrange and Bardin (1995) were able to detect $10^{2}$ Nitrobacter sp. cells from 0.6 grams of soil having a high organic content. Picard et al. (1992) reported a detection limit of $10^{4}$ cells $\mathrm{gram}^{-1}$ from moderately organic soil. Berthelet et al. (1996) reported a sensitivity of between $10^{1}$ and $10^{2}$ cells gram $^{-1}$ of forest soil, however, they used nested PCR to achieve this sensitivity. Cullen et al. (1998) were able to detect 300 genetically modified Rhizobia cells. gram $^{-1}$ soil of unknown organic content. Smalla et al. (1993) were able to detect $3 \times 10^{3}$ cells gram $^{-1}$ of soil using an organism that had 3 copies of the target gene per cell. Although the seeding assay used in the current study gave a sensitivity that was quite high, the sensitivity of the current protocol for detecting native bacteria in soil may be somewhat lower since indigenous soil bacteria are more intimately associated with soil particles, and therefore harder to break than cells grown in pure culture and then added to soil (Cullen et al. 1998).

We also have been successful in amplifying functional genes from unseeded soils (Figure 3 ). These genes are naturally in lower abundance than rDNA genes and only found in a small subset of the bacteria in any particular soil sample. Using primers directed at the nifH gene encoding the small subunit of nitrogenase (Zehr and McReynolds, 1989; Ueda et al., 1995), we generated the expected 464bp fragment with soil extracts from rice paddies at Southeast Missouri State University, tallgrass prairie from the Ninnescah field station at Wichita State University, and a hypersaline sandy soil from the Great Salt Plains of Oklahoma. Clone libraries for RFLP analyses and sequencing can be generated from these PCR amplicons and the diversity of functional guilds estimated.

\section{Acknowledgements}

We acknowledge Tom Bechert, Paula Fernandes, Brian Meehan, Melissa Kovach, Melissa Mundo, Prithi Rashid, and Lisa Witte for their help with the soil extractions and analyses, Jinesh Jain for performing the ICP-MS spectroscopy, Dennis Birdsell for his help with the ICPOES spectroscopy and other soil analyses, and James Seidler for his help in preparing the soil samples for analysis. We also would like to thank D.C.L. Kass and Mohammed Dore for the Costa Rican rainforest soil, Jean and Everett Laursen for the agricultural soil, Andrew Laursen for the marine sediment, Gene Stevens for the ricefield soil, the Indiana Nature Conservancy for permission to collect the Spinn Prairie soil, and Biosphere 2 for the desert soil. We thank Ronald Olsen for his gift of $P$. putida mt-2 strain and Madilyn Fletcher for the $P$. fluorescens kanamycin-resistant mutant. Finally, we acknowledge Chevron Research and Technology Corporation and the Departments of Biological Sciences 
at University of Notre Dame and Wichita State University for financial support.

\section{References}

Atlas, R.M., Sayler, G., Burlage, R.S., and Bej, A.K. 1992. Molecular approaches for environmental monitoring of microorganisms. BioTechniques 12: 706-717.

Bruce, K.D., Hiorns, W.D., Hobman, J.L., Osborn, A.M., Strike, P., and Ritchie, D.A. 1992. Amplification of DNA from native populations of soil bacteria by using the polymerase chain reaction. Appl. Environ. Microbiol. 58: 3413-3416.

Courtois, S., Frostegård, Å., Göransson, P., Depret, G., Jeannin, P., and Simonet, P. 2001. Quantification of bacterial subgroups in soil: comparison of DNA extracted directly from soil or from cells previously released by density gradient centrifugation. Environ. Microbiol. 3: 431439.

Cullen, D.W. and Hirsch, P.R. 1998. Simple and rapid method for direct extraction of microbial DNA from soil for PCR. Soil Biol. Biochem. 30: 983-993.

Demeke, T. and Adams, R.P. 1992. The effects of plant polysaccharides and buffer additives on PCR. BioTechniques 12: 332-333.

Edgcomb, V.P., McDonald, J.H., Devereux, R., and Smith, D.W. 1999. Estimation of bacterial cell numbers in humic acid-rich salt marsh sediments with probes directed to 16S ribosomal DNA. Appl. Environ. Microbiol. 65: 15161523.

Edwards U., Rogall H., Blöcker H., Emde M., and Böttger E.C. 1989. Isolation and direct complete nucleotide determination of entire genes. Characterization of a gene coding for 16 S ribosomal RNA. Nucl. Acids Res. 17: 78437853.

Erb, R.W. and Wagner-Döbler, I. 1993. Detection of polychlorinated biphenyl degradation genes in polluted sediments by direct DNA extraction and polymerase chain reaction. Appl. Environ. Microbiol. 59: 4065-4073.

Frostegård, Å., Courtois, S., Ramisse, V., Clerc, S., Bernillon, D., Le Gall, F., Jeannin, P., Nesme, X., and Simonet, P. 1999. Quantification of bias related to each step of an optimized protocol to extract, purify, and amplify DNA from soils. Appl. Environ. Microbiol. 65: 5409-5420.

Greaves, M.P. and Wilson, M.J. 1969. The adsorption of nucleic acids by montmorillonite. Soil Biol. Biochem. 1: 317-323.

Herrick, J.B., Madsen, E.L., Batt, C.A., and Ghiorse, W.C. 1993. Polymerase chain reaction amplification of naphthalene-catabolic and 16S rRNA gene sequences from indigenous sediment bacteria. Appl. Environ. Microbiol. 59: 687-694.

Holben W.E. 1994. Isolation and purification of bacterial DNA from soil. In: Methods of Soil Analysis, Part 2. Microbiological and Biochemical Properties. Soil Science Society of America, Madison. p. 727-751.

Holben, W.E., Jansson, J.K., Chelm, B.K., and Tiedje, J.M. 1988. DNA probe method for the detection of specific microorganisms in the soil bacterial community. Appl. Environ. Microbiol. 54: 703-711.

Holley, R.W., Apgar, J., Doctor, B.P., Farrow, J., Marini,
M.A., and Merrill, S.H. 1961. A simplified procedure for the preparation of tyrosine- and valine-acceptor fraction of yeast "soluble ribonucleic acid." J. Biol. Chem. 236: 200-202.

Jackson, C.R., Harper, J.P., Willoughby, D., Rodin, E.E., and Churchill, P.F. 1997. A simple, efficient method for the separation of humic substances and DNA from environmental samples. Appl. Environ. Microbiol. 63: 4993-4995.

Jacobsen, C.S. and Rasmussen, O.F. 1992. Development and application of a new method to extract bacterial DNA from soil based on separation of bacteria from soil with cation-exchange resin. Appl. Environ. Microbiol. 58:24582462.

Josephson, K.L, Pillai, S.D, Way, J., Gerba, C.P., and Pepper, I.L. 1991. Fecal coliforms in soil detected by polymerase chain reaction and DNA-DNA hybridizations. Soil Sci. Soc. Am. J. 55: 1326-1332.

Lorenz, M.G. and Wackernagel, W. 1987. Adsorption of DNA to sand and variable degradation rates of adsorbed DNA. Appl. Environ. Microbiol. 53: 2948-2952.

Lovell, C.R. and Piceno, Y. 1994. Purification of DNA from estuarine sediments. J. Microbiol. Meth. 20: 161-174.

Madsen, E.L. 1998. Epistemology of environmental microbiology. Environ. Sci. Technol. 32: 429-439.

Markov, G.G. and Ivanov, I.G. 1974. Hydroxyapatite column chromatography in procedures for isolation of purified DNA. Analyt. Biochem. 59: 555-563.

Moré, M.I., Herrick, J.B., Silva, M.C., Ghiorse, W.C., and Madsen, E.L. 1994. Quantitative cell lysis of indigenous microorganisms and rapid extraction of microbial DNA from sediment. Appl. Environ. Microbiol. 60: 1572-1580. Ogram, A., Sayler, G.S., and Barkay, T. 1987. The extraction and purification of microbial DNA from sediments. J. Microbiol. Meth. 7: 57-66.

Ogram, A., Sayler, G.S., Gustin, D., and Lewis, R.J. 1988. DNA adsorption to soils and sediments. Environ. Sci. Technol. 22: 982-984.

Picard, C., Ponsonnet, C., Paget, E., Nesme, X., and Simonet, P. 1992. Detection and enumeration of bacteria in soil by direct DNA extraction and polymerase chain reaction. Appl. Environ. Microbiol. 58: 2717-2722.

Porteous, L.A. and Armstrong, J.L. 1991. Recovery of bulk DNA from soil by a rapid, small-scale extraction method. Curr. Microbiol. 22: 345-348.

Porteous, L.A., Seidler, R.J., and Watrud, L.S. 1997. An improved method for purifying DNA from soil for polymerase chain reaction amplification and molecular ecology applications. Molec. Ecol. 6: 787-791.

Ranjard, L., Poly, F., Combrisson, J., Richaume, A., and Nazaret, S. 1998. A single procedure to recover DNA from the surface or inside aggregates and in various size fractions of soil suitable for PCR-based assays of bacterial communities. Eur. J. Soil Biol. 34: 89-97.

Rochelle, P.A. and Olson, B.H. 1991. A simple technique for electroelution of DNA from environmental samples. BioTechniques 11: 724-728.

Sambrook, J., Fritsch, E.F., and Maniatis, T. 1989. Molecular Cloning: A Laboratory Manual, 2nd ed. Cold Spring Harbor Laboratory Press, Plainview, NY.

Schneegurt, M.A. and Kulpa, C.F., Jr. 1998. Review: The 
application of molecular techniques in environmental biotechnology for monitoring microbial systems. Biotechnol. Appl. Biochem. 27: 73-79.

Selenska, S. and Klingmüller, W. 1991. DNA recovery and direct detection of Tn5 sequences from soil. Lett. Appl. Microbiol. 13: 21-24.

Smalla, K., Cresswell, N., Mendonca-Hagler, L.C., Wolters, A., and van Elsas, J.D. 1993. Rapid DNA extraction protocol from soil for polymerase chain reaction-mediated amplification. J. Appl. Biotechnol. 74: 78-85.

Steffan, R.J., Goksøyr, J., Bej, A.K., and Atlas, R.M. 1988. Recovery of DNA from soils and sediments. Appl. Environ. Microbiol. 54: 2908-2915.

Tebbe, C.C. and Vahjen, W. 1993. Interference of humic acids and DNA extracted directly from soil in detection and transformation of recombinant DNA from bacteria and a yeast. Appl. Environ. Microbiol. 59: 2657-2665.

Torsvik, V.L. 1980. Isolation of bacterial DNA from soil. Soil Biol. Biochem. 12: 15-21.

Torsvik, V., Goksøyr, J., and Daae, F.L. 1990. High diversity in DNA of soil bacteria. Appl. Environ. Microbiol. 56: 782787.

Tsai, Y.L. and Olson, B.H. 1990. Effects of $\mathrm{Hg}^{2+}, \mathrm{CH}_{3}-\mathrm{Hg}^{+}$, and temperature on the expression of mercury resistance genes in environmental bacteria. Appl. Environ. Microbiol.
56: 3266-3272.

Tsai, Y.-L. and Olson, B.H. 1991. Rapid method for direct extraction of DNA from soil and sediments. Appl. Environ. Microbiol. 57: 1070-1074.

Tsai, Y.-L. and Olson, B.H. 1992. Rapid method for the separation of bacterial DNA from humic substances in sediments for polymerase chain reaction. Appl. Environ. Microbiol. 58: 2292-2295.

Ueda, T., Suga, Y., Yahiro, N., and Matsuguchi, T. 1995. Remarkable $\mathrm{N}_{2}$-fixing bacterial diversity detected in rice roots by molecular evolutionary analysis of nifH gene sequences. J. Bacteriol. 177: 1414-1417.

Volossiouk, T., Robb, E.J., and Nazar, R.N. 1995. Direct DNA extraction for PCR-mediated assays of soil organisms. Appl. Environ. Microbiol. 61: 3972-3976.

Weyant, R.S., Edmonds, P., and Swaminathan, B. 1990. Effect of ionic and nonionic detergents on the Taq polymerase. Biofeedback 9: 308-309.

Zehr, J.P. and McReynolds, L.A. 1989. Use of degenerate oligonucleotides for amplification of the nifH gene from the marine cyanobacterium Trichodesmium thiebautii. Appl. Environ. Microbiol. 55: 2522-2526.

Zhou, J., Bruns, M.A., and Tiedje, J.M. 1996. DNA recovery from soils of diverse composition. Appl. Environ. Microbiol. 62: 316-322. 


\section{Further Reading}

Caister Academic Press is a leading academic publisher of advanced texts in microbiology, molecular biology and medical research. Full details of all our publications at caister.com

- MALDI-TOF Mass Spectrometry in Microbiology Edited by: M Kostrzewa, S Schubert (2016) www.caister.com/malditof

- Aspergillus and Penicillium in the Post-genomic Era Edited by: RP Vries, IB Gelber, MR Andersen (2016) www.caister.com/aspergillus2

- The Bacteriocins: Current Knowledge and Future Prospects Edited by: RL Dorit, SM Roy, MA Riley (2016)

www.caister.com/bacteriocins

- Omics in Plant Disease Resistance Edited by: V Bhadauria (2016) www.caister.com/opd

- Acidophiles: Life in Extremely Acidic Environments Edited by: R Quatrini, DB Johnson (2016) www.caister.com/acidophiles

- Climate Change and Microbial Ecology: Current Research and Future Trend

Edited by: J Marxsen (2016)

www.caister.com/climate

- Biofilms in Bioremediation: Current Research and Emerging Technologies

Edited by: G Lear (2016)

www.caister.com/biorem

- Microalgae: Current Research and Applications Edited by: MN Tsaloglou (2016) www.caister.com/microalgae

- Gas Plasma Sterilization in Microbiology: Theory, Applications, Pitfalls and New Perspectives Edited by: H Shintani, A Sakudo (2016) www.caister.com/gasplasma

- Virus Evolution: Current Research and Future Directions Edited by: SC Weaver, M Denison, M Roossinck, et al. (2016) www.caister.com/virusevol

- Arboviruses: Molecular Biology, Evolution and Control Edited by: N Vasilakis, DJ Gubler (2016) www.caister.com/arbo

- Shigella: Molecular and Cellular Biology Edited by: WD Picking, WL Picking (2016) www.caister.com/shigella

-Aquatic Biofilms: Ecology, Water Quality and Wastewater Treatment

Edited by: AM Romaní, H Guasch, MD Balaguer (2016)

www.caister.com/aquaticbiofilms

- Alphaviruses: Current Biology

Edited by: S Mahalingam, L Herrero, B Herring (2016)

www.caister.com/alpha

- Thermophilic Microorganisms

Edited by: F Li (2015)

www.caister.com/thermophile
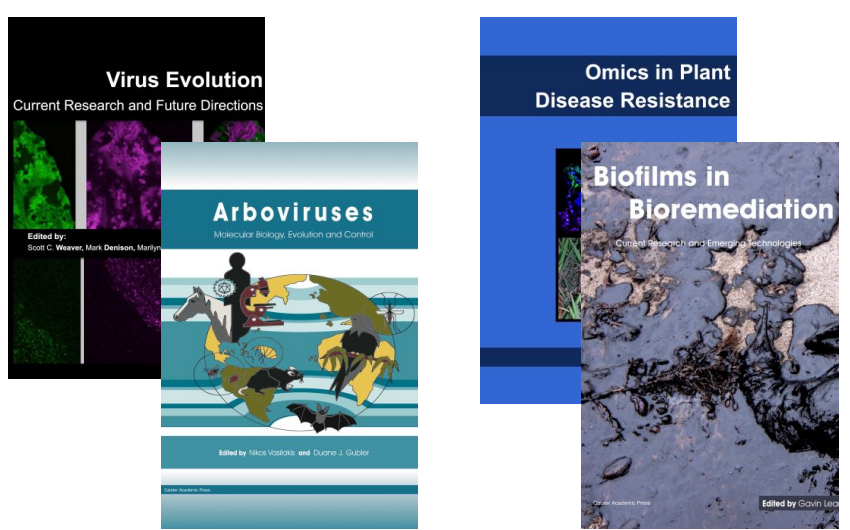
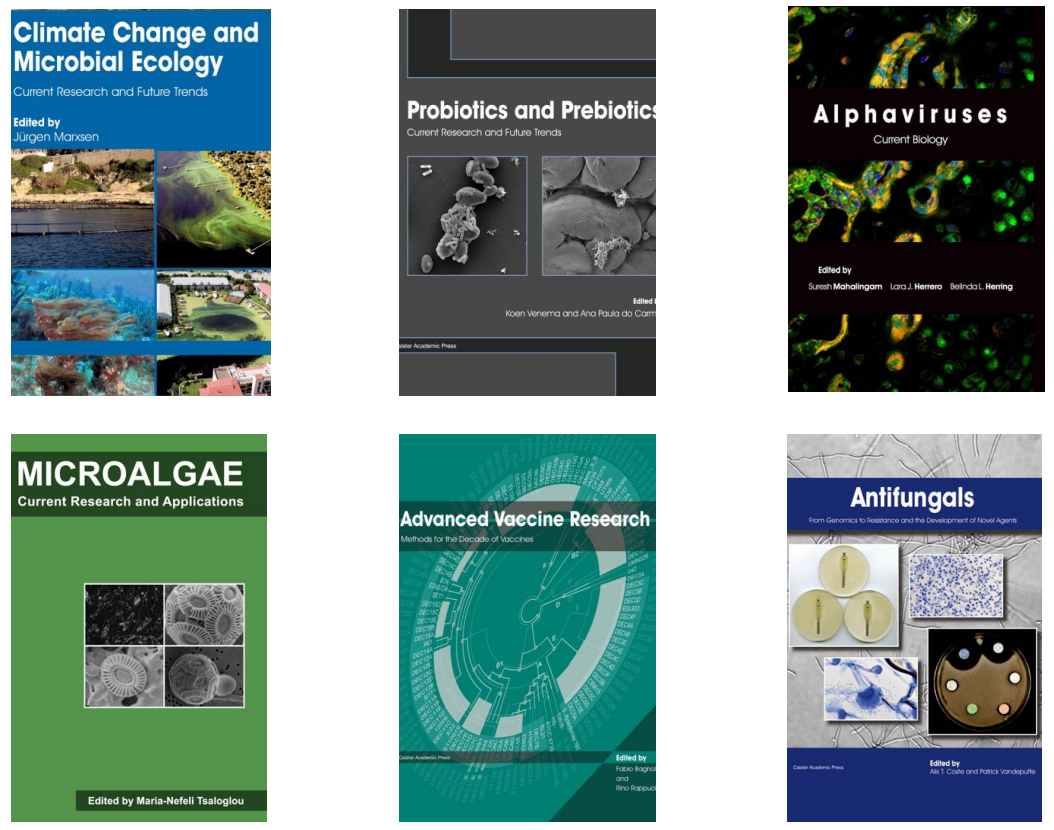

- Flow Cytometry in Microbiology: Technology and Applications Edited by: MG Wilkinson (2015) www.caister.com/flow

- Probiotics and Prebiotics: Current Research and Future Trends Edited by: K Venema, AP Carmo (2015) www.caister.com/probiotics

- Epigenetics: Current Research and Emerging Trends Edited by: BP Chadwick (2015) www.caister.com/epigenetics2015

- Corynebacterium glutamicum: From Systems Biology to Biotechnological Applications

Edited by: A Burkovski (2015)

www.caister.com/cory2

- Advanced Vaccine Research Methods for the Decade of Vaccines

Edited by: F Bagnoli, R Rappuoli (2015)

www.caister.com/vaccines

- Antifungals: From Genomics to Resistance and the Development of Novel Agents

Edited by: AT Coste, P Vandeputte (2015)

www.caister.com/antifungals

- Bacteria-Plant Interactions: Advanced Research and Future Trends Edited by: J Murillo, BA Vinatzer, RW Jackson, et al. (2015) www.caister.com/bacteria-plant

\section{- Aeromonas}

Edited by: J Graf (2015)

www.caister.com/aeromonas

- Antibiotics: Current Innovations and Future Trends

Edited by: S Sánchez, AL Demain (2015)

www.caister.com/antibiotics

- Leishmania: Current Biology and Contro Edited by: S Adak, R Datta (2015) www.caister.com/leish2

- Acanthamoeba: Biology and Pathogenesis (2nd edition) Author: NA Khan (2015)

www.caister.com/acanthamoeba2

- Microarrays: Current Technology, Innovations and Applications Edited by: Z He (2014)

www.caister.com/microarrays2

- Metagenomics of the Microbial Nitrogen Cycle: Theory, Methods and Applications

Edited by: D Marco (2014)

www.caister.com/n2 